\title{
Probe into the Training Mode of Industrial Design Talents under the Background of Innovation and Pioneering
}

\author{
Sun Zhi-xue \\ Department of Industrial Design, School of ME \\ Shaanxi Sci-tech University \\ Hanzhong 723000, China \\ sxlgszx@163.com \\ Liu Chun-rong \\ School of ME \\ Shaanxi Sci-tech University \\ Hanzhong 723000, China \\ 1632473267@qq.com
}

\author{
Zhang Dong-sheng \\ School of ME \\ Shaanxi Sci-tech University \\ Hanzhong 723000, China \\ 863019288@qq.com
}

\author{
Wang Xiao-jun \\ Department of Industrial Design, School of ME \\ Shaanxi Sci-tech University \\ Hanzhong 723000, China \\ 29577767@qq.com
}

\author{
Liu Jia \\ Department of Industrial Design, School of ME \\ Shaanxi Sci-tech University \\ Hanzhong 723000, China \\ 459484755@qq.com
}

\begin{abstract}
Under the background of public entrepreneurship and innovation, to promote the development of industrial design in our school, the talent training mode of which was explored. Firstly, this paper reviewed the course of running a major of industrial design briefly; secondly, explained the methods and ways of personnel training; finally, proposed a set of innovative talents training mode construction method, and made a prospect for the future professional construction ideas and directions. All these will have certain guiding significance and promotion value to the cultivation of innovative talents in industrial design.
\end{abstract}

Keywords-innovation and entrepreneurship;industrial design; personnel training; exploration

\section{REVIEW OF Professional CONSTRUCTION PROCESS}

Innovation driven development strategy is an important national strategy in china, and innovation and pioneering is the main theme of the times. Industrial design is one of the most important professional in many design majors, which is an important support of innovation driven development, and an important foundation for the realization of " 2025 " in china.

Shaanxi Sci-tech University industrial design professional was founded in 2002 currently has 8 full-time teachers, 1 professor, 1 associate professor and 6 lectures. There are more than 200 students in the school, cumulative training of outstanding graduates the 10 session of nearly 600 people. After more than 10 years development, preliminary already formed a certain characteristics, advantages and achieved a number of landmark results, quiet well known in the inside and outside the province of industrial design professionals. All these did not divide with solicitude and support from the school and school leaders at all levels, also benefited from the professional teaching team members.

In recent years, students in various competitions had won the International Gold Award, national first prize and second prize, provincial first prize and second prize nearly 100, all these have won honor for the school. Students postgraduate entrance examination rate was among the best, the quality of the employment was relatively high. Industrial design had excellence performance in various types of assessment now has become a new growth point of teaching, scientific research and other work in Shaanxi Sci-tech University.

\section{Methods AND Approaches of ProfessionAL CONSTRUCTION PERSONNEL TRAINING}

After more than 10 years construction and development, the special features of industrial design in our school were mainly reflected in the following 4 aspects:

A. Curricular and Extracurricular: Two-track, teachers and students worked together to lay a solid foundation

Classroom teaching is the main way for students to learn, and the main battlefield of teachers teaching and educating people. Under the guidance of excellent teaching tradition in schools and colleges, the teacher organized teaching and 
teaching link strictly according to the teaching standard. Of the eight teachers, three of them are art majors, at the beginning of their work; we have had repeatedly fierce "battles" about teaching norms, such as design sketching, design techniques. The teaching methods were changed from master hand handle, one to one counseling to a group class. Firstly, the teacher talked about the main points, then demonstrated, finally did dispersed guidance, many teachers were not able to stand, their mouth parched and tongue scorched after class because of a large amount of work-a class for 4 hours. What impressed me most was several young teachers who just took part in the work; they were faced with the improvement of knowledge structure, learning and training of teaching basic skills, transformation of teaching skills. Lacking of teachers, so these young teachers must be on the podium when they just entered Shaanxi Sci-tech University, without any respite, and they were art majors before, now faced with engineering class of students, so these young women teachers have paid ten times hard work than ordinary teachers, they did a good job in the classroom teaching, laid a solid foundation for the quality of personnel training.

Extracurricular learning is an effective supplement to the classroom teaching, an effective channel for students to learn the subjective initiative and creativity, and it can effectively apply the classroom knowledge and give full play to the main role of the students. Decided by the professional nature, there was no fixed pattern for many jobs we have arranged. Each small task was a design task, which needed to be completed from creativity to expression by students, during this process, there was no formula can be set, design results were also different, and any similarity was purely plagiarism. So the pressure of the students was very high, no hard work was difficult to complete, copy was no place to copy. The majority of the students can turn this huge pressure into learning motivation, and have a certain growth in the first, second and third grade compared to utterly ignorant of the art and without any foundation when they were just entering college. In addition to learning the professional knowledge, students also need to experience the life when after class. The essence and purpose of the industrial design is "creating the reasonable way of life and leading the future of people's lives", imagine, if industrial students do not know live, how to complete the design? How did the products they designed serve for people's life and production? So we have asked students should focus on the experience of life in the four years of college life, the weekend must be out of school and go to the society, understand the society requirements, such as the form, color, materials, structure, function, principles, brands and marketing models of all kinds of living things in shopping malls. Through the observation and study of their own, may be more than the teacher to say a few results, but also conducive to digestion and absorption of knowledge, meanwhile can improve students' self-cultivation.

\section{B. Application and practice: training innovative talents in industrial design}

Industrial design is the unity of "science and aesthetics", "technology and art", which is easy to say, but hard to do. The key is to highlight the application, and pay attention to practice. Industrial design is not engage in technological invention, but the design of the products must have a scientific basis and technical support, otherwise it will be castles in the air; Industrial design is not pure art, emphasizing the application of aesthetics in product design, in line with the needs of the public aesthetic, to create the form of beauty, but it is not the personality of the publicity, to be suitable for industrial production. The category of industrial products is very wide, so the teacher conducted their guidance should be based on students' strengths and interests, implementing individualized education, giving students more rational, directional guidance, hence to cultivate students' innovation ability.

Firstly, pay attention to practice and highlight the application. Industrial design is a subject which is focusing on the aesthetics and science, unifying the art and technology, taking into account the aesthetic and practical, and the purpose of which is to create a delicate life for peoples' life and service.

Secondly, contact with society and company actively, understand social needs and seek creative sources. Like "beautiful liuba youth flying" tourism logo design, "hanzhong clevermother” arts and crafts design, hanzhong special tourism souvenirs design activities we all have attended, and these activities all have attended our teaching process now. Our teaching was not empty talk and doing whatever we like individually in the ivory tower, but closely combined with the regional economy, aiming at the leading industries, making teaching materials come from production and life practice, served the local economy in the end.

Finally, exercises of engineering practice. Encourage students to enterprises, out of school, even if it was from sweeping the floor and taking the pot. When training the talents who meet the design requirements, we must understand the production, the market, and to conduct design practice in the enterprise, experience the hardships of survival, exercise the ability to job, the accumulation of professional knowledge, familiar with the design process ${ }^{[1]}$. There had seven holidays in four years of undergraduate study; we have arranged "vacation homework" every year. This method is not our original, but from professor Li Leshan, Department of industrial design, School of mechanical design, Xi'an Jiao Tong University. As one of the 2012 freshmen winter vacations "integrating into their family life", finding the longest life product in their home, and showing them in different angles, this homework made students having an intuitive feelings of form, color, materials, function, price, and etc. This homework was completed by students themselves voluntarily, and reported in oral and written form, the enthusiasm was very high and the effect was also very good. For the second assignment, went to the company and took part in the fieldwork, from being introduced to sought post by themselves, from cleaning, security to the international professional design positions, there had seven job hunting and work experiences in seven holidays. If every holiday in accordance with 1.5 months, students learned more than 10 months in four years, this was equivalent to five years. The most critical was that this was seven work experiences, the annual employment statistics by the end may $70 \%$, a monthly salary of the first month was more than 2500, among these 
jobs were Group of the United States, Foxconn, Great Wall Automobile, Geely Automobile and BYD Automobile.

There now has shape based laboratory, man machine engineering laboratory, model building laboratory. Cumulatively invested more than 600000 yuan for 10 years, currently has a normal operation. With an open laboratory, a decentralized management provided convenience for all the students who like industrial design.

\section{Motivation and innovation: building a good style of study, improving the quality of professional training in industrial design}

Let students participate in competition, not to win the prize, but to popularize innovative activities, build a better design atmosphere, construct excellent style of study and cultivate high quality social demand of talents. In recent years, industrial design major has made obvious achievements in students' science and technology innovation and the quality of talent training. The students who participated in science and technology innovation activities have been highly evaluated by many famous enterprises and universities in employment and postgraduate entrance examination.

School leaders attached importance to the ideological, and organized well, department teachers dedicated selfless, students cooperated actively. Encouraged students to participate in all kinds of competitions actively, and built a resource library complete system combined with professional training program. Freshman mainly participated in school graphic design contests, sophomore mainly participated in school, city product design contests, and junior based their competitions on province inside and outside of the professional and high level of the industry. Teachers involved in students' each composition spontaneously and actively, which made students cleared the direction and improved quickly. The time of each contest's collection was urgent, generally about 1-2 months. Students not only needed to complete course leaning tasks but also prepare for all kinds of competitions. "Dawn says good night" was their real life before they participated in the contests. They raced against the clock, and fight with their own will. It was the indomitable will and encouragement between students and teachers that created one after another splendid. For example, national car design competition (the Oscar of car design) in 2011, it is the top level car design competition in our country. The competition is aimed at mining car design master of Chinese future. Yang $\mathrm{Xu}$ won the qualification for the competition, accounted for one-fortieth seats in the country. He was on the list as well as Tsinghua University, Hunan University and Jiangnan University, and received a high praise from Professor CCS (Detroit Creative Design Institute). The car design team of the class of 2010 reached the final in 2013, and they were invited to attend the finals and awards ceremony in Shanghai. Finally, they competed with 53 pieces of work related awards. At present, our school rakes 33 at CDN accumulate points, won a place for our school in the field of international car design.

The competition was just a practice platform applied to realize a complement with class, which fundamental purpose was promoting the construction of study style. Introduced competition into teaching, improved students' enthusiasm and encouraged students to participate in a variety of technology activities in their extra-curricular time. As the saying 'A single spark can start a prairie fire' said, we can let the class to promote the academy, and even influent the whole school style of study. 'A single flower does not make spring, while one hundred flowers in full blossom bring the spring to the garden', the big environment of Institute of Mechanical Engineering and Shannxi Sci-Tech University can motivate us to endeavor as possible as we can.

In the aspect of teaching reform measures, implemented 'exhibition presses to review, to review the test', reformed evaluation system of examination, exhibited students' works, discussed between teachers and students, and improved students' ability to appreciation. Reformed teaching mode of classroom, set up a special subject discussion course, avoided what I said and cramming method teaching, aroused interest of students. At present, there are three teaching achievements won the two prizes of school levels, which adequately proved that the idea and way we innovated boldly could really got the recognition of experts and leaders.

Using all kinds of teaching resources widely, managed with innovation boldly, attracted high level teachers by 'borrow a boat out to sea'. Our teachers' were limited by strength and level, so we can make full use of a variety of effective quality resources to serve to our industrial design teaching. Professor Fan Chaoran of Xi'an University of Architecture and Technology, Professor Lu Changde of Northwestern Polytechnical University, Professor Li Jianhua of Xi'an University of Science and Technology and Professor Li Leshang of Xi'an Jiaotong University who were think-tank of our specialty construction. History of Industrial Design was written by Professor He Renke of Hunan University, selected classical chapter of which to learn for 4 classes and paused the class radio of Hunan University. Send students to go to Product Design Apartment of Shu-Te University in Taiwan for exchanging learning, which was not provided in undergraduate teaching of Industrial Design in Shaanxi Province. This activity let our students began to exchange learning with Taiwan. At the time of starting training plan revision of the 2014 edition, we invited Dr. Gou Bingchen and Dr. Wu Tong of Northwestern Polytechnical University to deliver their experience and instruct the students face to face. Meanwhile, Professor John Tan of Northumbria University in England who was invited to our school to make guidance. Though these were some concrete cases of our work, the thinking must be existed in every time, and we can realize that 'standing at the foot of Liancheng Mountain to look the global'. Otherwise, how can we start the teaching work of industrial design at Qin Ba Mountain Area and the foot of Liancheng Mountain? Not only can we learn knowledge at school, but communicated with teachers and other students, and watched some teaching video from other school professors online. Network narrowed the distance between us and the big city, and fostered closer relationships between us and other famous schools. We can scan foreign websites to select relevant information and essays by standing on the shoulders of the giants. 
D. Interest and guidance, make students stand on the podium of the international gold medal, and win a good reputation for our school at home and abroad

Just like raising children, the biggest motivation of learning is interest and encouragement. With the strong interest, Yang $\mathrm{Xu}$, Meng Shaobo, Zhou Xiang and other students regarded to accumulate knowledge all along, generated design concept through life experience, conducted design expression step by step after thinking and repeated deliberation, which made the products perfect gradually. Finally, the conceptual design will be turned to design schemes by interdisciplinary technologies and software.

For innovation design, students deemed that interest and hobby were very important. There existed strong belief and persistent for technology innovation in their minds. Such as the students of the class of 2010 who designed smart home appliances, controlled household appliances through telephone and internet, which has accomplished principle design with 'LED lamp' as controlled object at present. They completed the whole process by themselves, from programming, circuit board production to debugging. The technology realized before more than ten years, but it has not entered to people's life, mainly was the high cost, so it was not popularized. The cost of trial lamps from these students' products was less one tenth than foreign products. We have applied for intellectual property protection on these products.

As a teacher, in addition to professional guidance to the students, they should often encourage them. An old saying 'as long as you work hard, you will be more excellent ', which make them get the most forward power and motivate them keep on moving in the road of Industrial Design.

\section{Construct Training Models Of InNOVATiON PERSONNEL}

Combined with the concrete implementations method above, professional construction for ten years has formed innovation personnel training models based on the characteristics of highlight practical courses system. At first, it has formed a practical teaching system of ' 1234 ' model, namely, a curriculum group, two platforms, three modules and four ways. As the training of students' innovation ability as the core, and took enhancing students' production design ability as the main objective ${ }^{[2]}$. (Here again with the Pyramid shaped figure out, drawing illustration).

A curriculum group meant a practical teaching curriculum group, including skill course, experimental course. Two platforms referred to form the design practice platform of 'school-enterprise (society)', including practical teaching platform in-school and practical teaching platform of enterprise (society). Three modules referred to the formation of practical teaching models, including art, engineering and professional fundamental training module. Four ways referred to setting up four practical teaching links, including experimental course, design training, internship and design competition. Practice has proved that these reforms and explorations have achieved initial results.

\section{PROSPECT For FutURE WORK}

Although the preliminary professional construction has achieved initial results, there also existed many problems and deficiencies. We will exert ourselves under the guidance of 'article thirty of higher education', and do following things.

\section{A. Increase the construction of experimental platform}

Due to the aging of existing experimental platform, it is urgent to upgrade and reform the experiment platform and improve it, to meet the needs of teaching and scientific research. At the same time, due to continuous progress of science and technology and new equipment constantly emerging, we are facing some problems which including the upgrading and reforming of experimental platform, the application of new technology on 3D-Reverse Engineering System, 3D-Printing and so on.

\section{B. Strengthen international cooperation and broaden the channels of professional construction}

Based on the current exchange study of Taiwan, increased the quantities of sending students and enhanced guidance in the selected period. Students can learn advanced design theories and methods on overseas, meanwhile, combining with the actual situation in China. Meanwhile, developing joint cultivation with overseas and broadening the channels of personnel training, hence to cultivate high level specialized talents with international vision.

\section{Strength the training of teachers}

Make full use of western talent program, sent teachers to go abroad for further education and visited scholar program to increase teachers' teaching ability and scientific research ability, lay the foundation for cultivation of high level talents.

\section{Transform design capacity into productivity as soon as possible, serve to local economic development}

Combined with regional characteristics of Qin $\mathrm{Ba}$ Mountain Area, produced a lot of design results during the teaching, such as tourism souvenirs design in Hanzhong, the development of new products of 'Han Zhong clever mother' cooperative and Production Form Design in equipment manufacturing industry. Transform design capacity into productivity as soon as possible, and make its own contribution to local economic development ${ }^{[3]}$.

\section{CONCLUSION}

The construction of industrial design is a very good explanation of the "innovation and entrepreneurship" strategy. Based on the review of the course of running a school of industrial design, the paper proposes a good way to cultivate talents in the process of professional construction, and expounds from 4 aspects specifically. Combined with these specific implementation methods, the construction system of the training mode was proposed, and formed a practical teaching system of ' 1234 ' model, namely, a curriculum group, two platforms, three modules and four ways. Ultimately, make a prospect of the professional construction of our school, 
improving and perfecting ourselves in the process of practice teaching, thereby cultivating more and more innovative talents.

\section{REFERENCES}

[1] Li Le-shan, Exploration on University of Research Type: Concept and Practice of PHA Education Type. Journal of Xi'an Jiaotong University(Social Sciences), 1st ed,vol.24, 2004, pp.72-79.

[2] Sun Zhi-xue, Construction on innovative practice teaching system for Industrial Design. Shaanxi Jiaoyu·Gaojiao, 2012, pp.55-56.

[3] Sun Zhi-xue, Analysis and exploration on the orientation of school running of Industrial Design in our school. Exam Week, 2010, pp.205206. 